\title{
A biomimetic approach to the synthesis of a mycolic acid motif
}

\author{
Cathryn H. S. Driver ${ }^{\mathrm{a}}$, Mohammed O. Balogun ${ }^{\mathrm{b}}$, Gianna Toschi ${ }^{\mathrm{a}}$, Jan A. Verschoor ${ }^{\mathrm{b}}$, Mark S. Baird ${ }^{\mathrm{c}}$, \\ Lynne A. Pilcher ${ }^{\mathrm{a}, *}$ \\ a Department of Chemistry, University of Pretoria, Pretoria 0002, South Africa \\ ${ }^{\mathrm{b}}$ Department of Biochemistry, University of Pretoria, Pretoria 0002, South Africa \\ ${ }^{\mathrm{c}}$ Department of Chemistry, University of Wales, Bangor, Gwynedd LL57 2UW, UK
}

\section{A R T I C L E I N F O}

\section{Article history:}

Received 17 November 2009

Revised 4 December 2009

Accepted 16 December 2009

Available online $\mathrm{xxxx}$

\begin{abstract}
A B S T R A C T
A new method for the stereoselective synthesis of the $(R, R)$ - $\beta$-hydroxy- $\alpha$-alkyl fatty acid fragment of mycolic acids, via an asymmetric anti-aldol reaction is reported. The 'mycolic acid motif fragment was prepared in three steps and $>98 \%$ ee.
\end{abstract}

(c) 2010 Elsevier Ltd. All rights reserved.

Keywords:

Tuberculosis

Mycolic acid

Mycolic acid motif

Asymmetric anti-aldol reaction

Mycolic acids 1 (MAs) are located in the protective wax coat of the cell wall of Mycobacterium tuberculosis and other mycobacteria. ${ }^{1}$ MAs consist of two main parts, a mycolic acid motif with a 22 or 24 carbon $\alpha$-alkyl chain and a $\beta$-hydroxy group, and a mero-mycolate chain with variable functional groups. ${ }^{2}$ The mycolic acid motif, common to MAs from all mycobacteria, usually has an $R, R$ configuration. ${ }^{3}$ These complex waxes are recognized by antibodies ${ }^{4}$ and therefore show potential for use in TB therapy and new diagnostic techniques such as biosensor assays. ${ }^{5}$ Furthermore, they have been shown to re-programme the macrophages to promote a telerogenic response in experimental asthma and are being explored for their potential in the prevention and treatment of asthma. ${ }^{6}$

Natural mycobacterial MAs are present as complex mixtures containing different functionalities $\mathrm{X}$ and $\mathrm{Y}$, and a range of homologues with different chain lengths. ${ }^{1,2}$ To fully understand the biological role of MAs there is a need for the synthesis of individual acids with known stereochemistry. In the biosynthesis of mycolic acids, the $\alpha$ and $\beta$ carbons are joined in a Claisen-type condensation to give a $\beta$-keto product which is selectively reduced. ${ }^{7}$ In published syntheses of the mycolic acid motif, two stereocentres are inserted consecutively in three to five steps. ${ }^{8,9}$ We now report a more biomimetic approach (Scheme 1 ) whereby an auxiliary-mediated anti-aldol reaction gives the $\alpha$-alkyl- $\beta$-hydroxy product 2 in the required $R, R$ configuration in one step. We have adapted the

\footnotetext{
* Corresponding author. Tel.: +27 12420 5384; fax: +27 124204687 .

E-mail address: lynne.pilcher@up.ac.za (L.A. Pilcher).
}

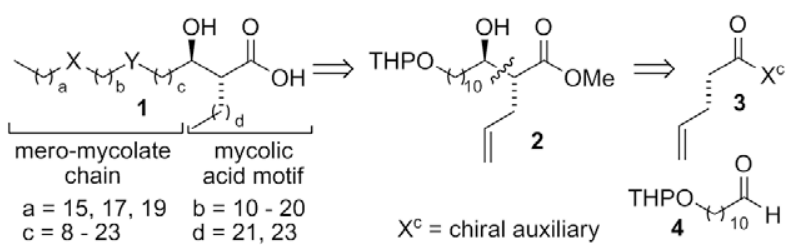

Scheme 1. Mycolic acid structure ${ }^{1,2}$ and retrosynthetic analysis.

method developed by Kurosu and Lorca, ${ }^{10}$ to couple saturated carboxylic acids with short chain aldehydes for the synthesis of $\mathbf{2}$, containing a terminal alkene. This can be used to extend the $\alpha$-alkyl chain in the mycolic acid motif to its full length of 22 or 24 carbons as described by Toschi and Baird, ${ }^{9}$ and can be extended to the full MA by reaction at the THPO-group. ${ }^{11}$

The norephedrine-based auxiliary $\mathbf{6}$ was attached to both the required unsaturated acid $\mathbf{5 a}$ and a saturated acid $\mathbf{5 b}$ to give chiral esters $\mathbf{3 a}$ and $\mathbf{3 b}$ (Scheme 2). The corresponding zirconium enolates were prepared by treatment with LDA and transmetalation with a zirconium complex $\left(\mathrm{Cp}_{2} \mathrm{ZrCl}_{2}\right)$. Coupling of these enolates to a variety of aldehydes $\mathbf{4 a - d}$ showed that chain length and functionality in the aldehyde had little effect on the outcome of the reaction, but the introduction of the terminal alkene in the enolate led to lower yields ( $30-45 \%$ for $3 \mathbf{a}$ with $\mathbf{4 a - d}$ vs $50 \%$ for $\mathbf{3 b}$ with $\mathbf{4 b}$ / d). Using freshly prepared LDA, strictly anhydrous conditions, a constant temperature of $-78{ }^{\circ} \mathrm{C}$ (monitored by an internal probe) and dropwise addition of the reagents, the anti-aldol product $\mathbf{7 a}$ was obtained from 3a and $\mathbf{4 a}$ on a $1 \mathrm{~g}$ scale in $45 \%$ yield with high 

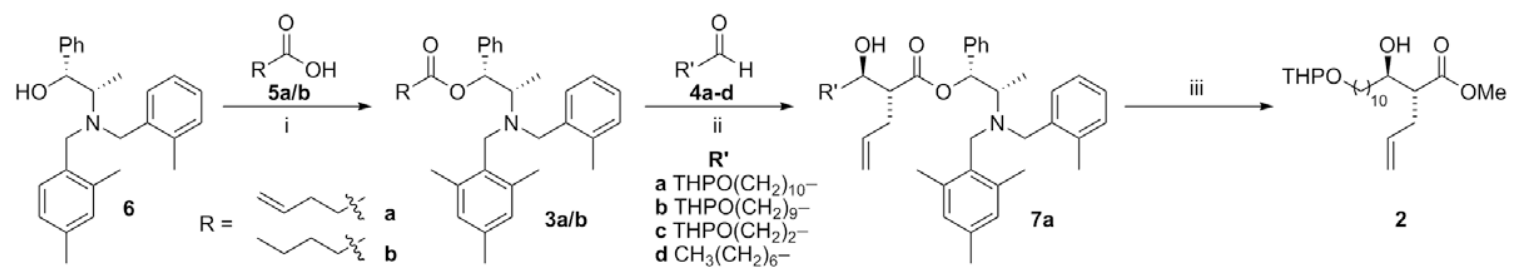

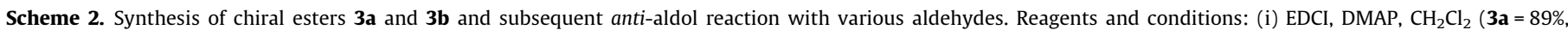
3b = 91\%); (ii) LDA, $\mathrm{Cp}_{2} \mathrm{ZrCl}_{2}, \mathrm{THF},-78{ }^{\circ} \mathrm{C}$; (iii) $\mathrm{Na}(\mathrm{s}), \mathrm{MeOH}(70 \%$ ).

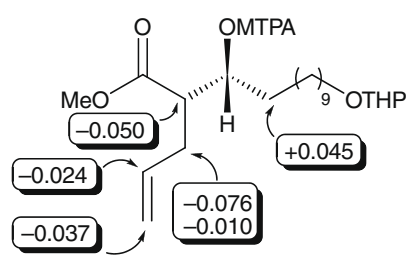

Figure 1. MTPA ester of compound $2\left(\Delta \delta_{\mathrm{H}}\right.$ values in ppm).

\section{Table 1}

Comparison of the ${ }^{13} \mathrm{C}$ NMR alkene signals (in ppm) of diastereomers $\mathbf{2}$ with the literature compound $\mathbf{8}^{11}$

\begin{tabular}{llll} 
& & & \\
\hline Carbon & $\mathbf{2}$ & epi-2 & anti-8 \\
\hline $\mathrm{HC}=\mathrm{CH}_{2}$ & 134.9 & 135.6 & 134.9 \\
$\mathrm{HC}=\mathrm{CH}_{2}$ & 117.1 & 116.6 & 117.1 \\
\hline
\end{tabular}

diastereoselectivity (>98\%) (determined as described below) after separation from the two syn-diastereomers by flash chromatography. ${ }^{12}$ The chiral auxiliary was cleaved from aldol product $7 \mathbf{a}$ by transesterification with sodium methoxide, rather than reductively, ${ }^{10}$ to yield the methyl ester $\mathbf{2}(70 \%)$ (Scheme 2 ). The configuration of the hydroxy group in $\mathbf{2}$ was determined using Mosher's method, by conversion into the $(R)$ - and (S)-MTPA esters. ${ }^{13}$ The $\Delta \delta_{\mathrm{H}}$ values for the protons in the left and right segments (Fig. 1), respectively, indicated an $R$ configuration.

On standing in $\mathrm{CDCl}_{3}$ at room temperature for a week, the solution of $\mathbf{2}$ partly epimerized at the alpha position giving a mixture of anti- and syn-diastereomers. A comparison of the ${ }^{13} \mathrm{C}$ NMR data for the two diastereomers with those published for mycolic acid motif $\mathbf{8}^{11}$ demonstrated that the relative stereochemistry of $\mathbf{2}$ was anti (Table 1).

This synthesis of the mycolic acid motif methyl ester 2 represents a novel approach to a key intermediate that has been used to prepare mycolic acids. ${ }^{11}$ The use of anti-aldol methodology reduces the number of steps required from six, ${ }^{11}$ to two. Prior to the removal of the auxiliary, the diastereomeric products are readily separated giving the desired $R, R$-product in $>98 \%$ ee. The chiral auxiliary can be recovered and recycled, increasing the atom econ- omy of the process. By applying the method directly to the aldol reaction of mero-mycolate aldehydes and long chain acids, it is hoped that more efficient syntheses of a range of homologues of natural mycolic acids can be achieved.

\section{Acknowledgements}

The authors thank Mr. E. Palmer for the NMR spectra. Financial support was provided by the University of Pretoria and the $\mathrm{Na}$ tional Research Foundation of South Africa.

\section{Supplementary data}

Supplementary data associated with this article can be found, in the online version, at doi:10.1016/j.tetlet.2009.12.105.

\section{References and notes}

1. Minnikin, D. E. Lipids: Complex lipids, Their Chemistry, Biosynthesis and Roles. In The Biology of the Mycobacteria; Ratledge, C., Stanford, J., Eds.; Academic Press: San Diego, 1982; pp 95-184.

2. Watanabe, M.; Aoyagi, Y.; Mitome, H.; Fujita, T.; Naoki, H.; Ridell, M.; Minnikin, D. E. Microbiology 2002, 148, 1881-1902.

3. Minnikin, D. E.; Polgar, N. Chem. Commun. 1966, 648-649.

4. Schleicher, G. K.; Feldman, C.; Vermaak, Y.; Verschoor, J. A. Clin. Chem. Lab. Med. 2002, 40, 882-887.

5. Thanyani, S. T.; Roberts, V.; Siko, D. G.; Vrey, P.; Verschoor, J. A. J. Immunol. Methods 2008, 332, 61-72.

6. Korf, J. E.; Pynaert, G.; Tournoy, K.; Boonefaes, T.; Van Oosterhout, A.; Ginneberge, D.; Haegeman, A.; Verschoor, J. A.; De Baetselier, P.; Grooten, J. Am. J. Respir. Crit. Care Med. 2006, 174, 152-160.

7. Lee, R. E.; Armour, J. W.; Takayama, K.; Brennan, P. J.; Besra, G. S. Biochim. Biophys. Acta 1997, 1346, 275-284.

8. Al-Dulayymi, J.; Baird, M. S.; Roberts, E. Tetrahedron 2005, 61, 11939-11951.

9. Toschi, G.; Baird, M. S. Tetrahedron 2006, 62, 3221-3227.

10. Kurosu, M.; Lorca, M. J. Org. Chem. 2001, 66, 1205-1209.

11. Al-Dulayymi, J. R.; Baird, M. S.; Roberts, E.; Deysel, M.; Verschoor, J. A. Tetrahedron 2007, 63, 2571-2592.

12. Ester 3a $(1.1 \mathrm{~g}, 2.3 \mathrm{mmol})$ was added to a solution of freshly prepared LDA $(16 \mathrm{~mL}, 1.0 \mathrm{M})$ and $\mathrm{Cp}_{2} \mathrm{ZrCl}_{2}(0.7 \mathrm{mmol})$ in $\mathrm{THF}(8 \mathrm{~mL})$ at $-78^{\circ} \mathrm{C}$ under nitrogen. After $2 \mathrm{~h}, \mathrm{Cp}_{2} \mathrm{ZrCl}_{2}(5.8 \mathrm{mmol})$ in THF $(5 \mathrm{~mL})$ was added and $0.5 \mathrm{~h}$ later the aldehyde $\mathbf{4 a}(670 \mathrm{mg}, 2.6 \mathrm{mmol})$ in THF $(3.5 \mathrm{~mL})$ was added. The mixture was stirred at $-78^{\circ} \mathrm{C}$ for $2 \mathrm{~h}$, then the reaction was quenched with $1 \mathrm{M}$ $\mathrm{HCl}$. Flash chromatography gave product $7 \mathrm{a}$ in $45 \%$ yield. $v_{\max } / \mathrm{cm}^{-1}: 3509$, 2924,$1722 ; \delta_{\mathrm{H}}\left(500 \mathrm{MHz}, \mathrm{CDCl}_{3}\right): 7.22-7.06(7 \mathrm{H}, \mathrm{m}), 6.90(2 \mathrm{H}, \mathrm{d}, J=7.0 \mathrm{~Hz})$, $6.74(2 \mathrm{H}, \mathrm{s}), 6.01(1 \mathrm{H}, \mathrm{d}, J=8.0 \mathrm{~Hz}), 5.60-5.40(1 \mathrm{H}, \mathrm{m}), 4.91-4.70(2 \mathrm{H}, \mathrm{m}), 4.60$ $(1 \mathrm{H}, \mathrm{s}), 3.90-3.80(1 \mathrm{H}, \mathrm{m}), 3.75-3.60(4 \mathrm{H}, \mathrm{m}), 3.54-3.48(3 \mathrm{H}, \mathrm{m}), 3.44-3.38$ $(1 \mathrm{H}, \mathrm{m}), 3.37-3.30(1 \mathrm{H}, \mathrm{m}), 2.65-2.50(2 \mathrm{H}, \mathrm{m}), 2.49-2.44(1 \mathrm{H}, \mathrm{m}), 2.26(3 \mathrm{H}, \mathrm{s})$, $2.08(3 \mathrm{H}, \mathrm{s}), 2.03(6 \mathrm{H}, \mathrm{s}), 1.80-1.30(27 \mathrm{H}, \mathrm{m}) ; \delta_{\mathrm{C}}\left(75.4 \mathrm{MHz}, \mathrm{CDCl}_{3}\right): 174.2$, $139.2,138.5,137.4,136.7,136.2,134.4,131.3,130.9,130.0,128.9,127.8,126.9$ $125.3,117.2,98.8,77.2,71.5,67.7,62.3,55.5,50.9,50.4,47.3,35.5,33.6,30.8$, 29.6, 29.5, 29.3, 26.2, 25.8, 25.5, 22.7, 20.8, 20.0, 19.7, 19.2, 14.1, 9.8; HRMS (+ESI) calcd for $\mathrm{C}_{48} \mathrm{H}_{70} \mathrm{NO}_{5}[\mathrm{M}+\mathrm{H}]^{+}=740.5254$, found: 740.5248 .

13. Ohtani, I.; Kusumi, T.; Kashman, Y.; Kakisawa, H. J. Am. Chem. Soc. 1991, 113, 4092-4096. 